\title{
The influence of an extreme drought event in the fish community of a southern Europe temperate estuary
}

\author{
F. Martinho ${ }^{\text {a,*, }}$, R. Leitão ${ }^{\text {a }}$, I. Viegas ${ }^{\text {a }}$, M. Dolbeth ${ }^{\text {a }}$, J.M. Neto ${ }^{\text {a }}$, \\ H.N. Cabral ${ }^{\text {b }}$, M.A. Pardal ${ }^{\mathrm{a}}$ \\ ${ }^{\text {a }}$ Institute of Marine Research (IMAR), clo Department of Zoology, University of Coimbra, 3004-517 Coimbra, Portugal \\ ${ }^{\mathrm{b}}$ Instituto de Oceanografia, Faculdade de Ciências da Universidade de Lisboa, Campo Grande, 1749-016 Lisboa, Portugal
}

Received 13 March 2007; accepted 28 May 2007

Available online 20 July 2007

\begin{abstract}
Between 2003 and 2006, a severe drought occurred throughout the Mondego River catchment's area, inducing lower freshwater flows into the estuary. As a consequence, both 2004 and 2005 were considered as extreme drought events. From June 2003 to June 2006, the fish assemblage of the Mondego Estuary was sampled monthly in five stations during the night, using a $2 \mathrm{~m}$ beam trawl. Fish abundance was standardized as the number of individuals per $1000 \mathrm{~m}^{2}$ per season and the assemblage was analyzed based on ecological guilds: estuarine residents, marine juveniles, marine adventitious, freshwater, catadromous and marine species that use the estuary as a nursery area. A total of 42 species belonging to 23 families were identified, with estuarine residents and nursery species dominating the fish community. Variations in the fish community were assessed using non-metric MDS, being defined as three distinct periods: summer and autumn 2003, 2004/2005 and winter and summer 2006. The main drought-induced effects detected were the depletion of freshwater species and an increase in marine adventitious in 2004/2005, due to an extended intrusion of seawater inside the estuary and a significant reduction in abundance during the driest period of estuarine resident species. Nevertheless, from the management point of view, it could be stated that although some variations occurred due to environmental stress, the main core of the Mondego Estuary fish community remained relatively unchanged.
\end{abstract}

(C) 2007 Elsevier Ltd. All rights reserved.

Keywords: fish assemblages; ecological guilds; climatic changes; drought events; temperate estuary; Mondego

\section{Introduction}

The increasing rate of global climate change seen in the last century and the predictions to accelerate into the present one will significantly impact the Earth's oceans and coastal waters (Short and Neckles, 1999; Mirza, 2003). Stochastic events such as weather extremes can cause fluctuations in the conditioning factors but often affect the state directly, for example, by eliminating parts of populations (Scheffer et al., 2001). Extreme environmental events (e.g. extreme droughts/floods) can seriously change the amount of water flowing within river

\footnotetext{
* Corresponding author.

E-mail address: fmdm@ci.uc.pt (F. Martinho).
}

systems (Tallaksen et al., 1997). In estuaries, these effects have only been addressed in a few studies concerning invertebrates (Attrill et al., 1996; Attrill and Power, 2000) and fishes (e.g. Garcia et al., 2001; Ecoutin et al., 2005). Such environmental instability, combined with anthropogenic derived pressures such as dredging activities, waste water and general organic pollution, will have significant impacts on estuarine fish communities. Hence, understanding the effects of changes in freshwater flow on estuarine systems is crucial to comprehend more about the dynamics of these key ecosystems, since river discharge into many estuaries is substantially altered due to human socio-economic development and may be in fact sensitive to climate change (Gleick, 2003).

Estuaries have long been regarded as important sites for fish (e.g. Haedrich, 1983; McLusky and Elliott, 2004), and are 
characterized by a relatively low diversity but high abundance of individual taxa, most of which exhibit wide tolerance limits to the fluctuating conditions found within these systems (Whitfield, 1999). In order to simplify information and to allow a better comparison among different systems, Elliott and Dewailly (1995) defined the structure of the typical Atlantic Seaboard estuarine fish community, in terms of ecological guilds: estuarine residents, marine adventitious visitors, diadromous (catadromous or anadromous) migrant species, marine seasonal migrants, marine juvenile migrants which use estuaries as nursery grounds and freshwater adventitious species. Therefore, the knowledge of the effects and changes caused by environmental extreme variations on the above ecological groups should yield insights into the present status and to foresee future changes in fish communities.

Previous works regarding the Mondego Estuary fish community focused mainly on the structure according to the ecological guilds previously referenced and also on the importance of the estuary as a nursery area for commercial marine species (for further details see Jorge et al., 2002; Leitão et al., 2006, 2007; Martinho et al., 2007). As a general trend, in the last 15 years a major decline in species number from 1989-1992 to 2003/2004 was noticed, mostly freshwater species (Leitão et al., 2007). According to the same authors, this decline could be partially attributed to a change in the estuarine environment, as salinity increased over the past years due to continuous dredging activities to deepen the main shipping channel, within the estuary. Also, the decrease in the environmental quality of the estuary due to eutrophication pulses and consequent macroalgal blooms (Cardoso et al., 2004; Dolbeth et al., 2007) could have been responsible for the loss of less resilient species.

In Portugal, several weather extremes have been recorded in the past years. According to the Portuguese Weather Institute (http://web.meteo.pt/pt/clima/clima.jsp), 2003 was registered as the second hottest summer since 1931, with the longest heat wave since 1941. In 2004, an extremely dry year, precipitation levels were far below average. June 2004 was the hottest month since 1931. In the year 2005, which was also an extremely dry year, the lowest precipitation values since 1931 were registered. June and August 2005 were the second and third hottest months, respectively, since 1931. This year was considered as severe drought until September throughout the Portuguese territory, and was the harshest of the past 60 years. Until June 2006, 96\% of the Portuguese territory remained under weak drought conditions (Portuguese Weather Institute, http://web.meteo.pt/pt/clima/clima.jsp). This series of consecutive changes allowed a direct comparison between years of different hydrological regimes.

Within this framework of events, the objectives of this work were the following: (a) to identify the changes that occurred in the fish community of the Mondego Estuary along a three-year period, from June 2003 to June 2006; and (b) to assess if drought conditions influenced the distribution and composition of the fish community.

\section{Materials and methods}

\subsection{Study site}

The Mondego River Estuary $\left(40^{\circ} 08^{\prime} \mathrm{N}, 8^{\circ} 50^{\prime} \mathrm{W}\right)$ is a small intertidal system, located in the western coast of Portugal (Fig. 1). It comprises two arms (north and south) that separate at about $7 \mathrm{~km}$ from the shore and join again near the mouth. The north arm is deeper, with 5-10 $\mathrm{m}$ depth at high tide and tidal range of $2-3 \mathrm{~m}$, while the south arm is shallower, with $2-4 \mathrm{~m}$ depth at high tide and tidal range of $2-3 \mathrm{~m}$. The south arm is almost silted up in the upstream areas, which causes the freshwater to flow mainly by the north arm. The water circulation in the south arm is mainly dependent on the tides and on a small freshwater input, carried out through the Pranto River, a small tributary system, which is regulated

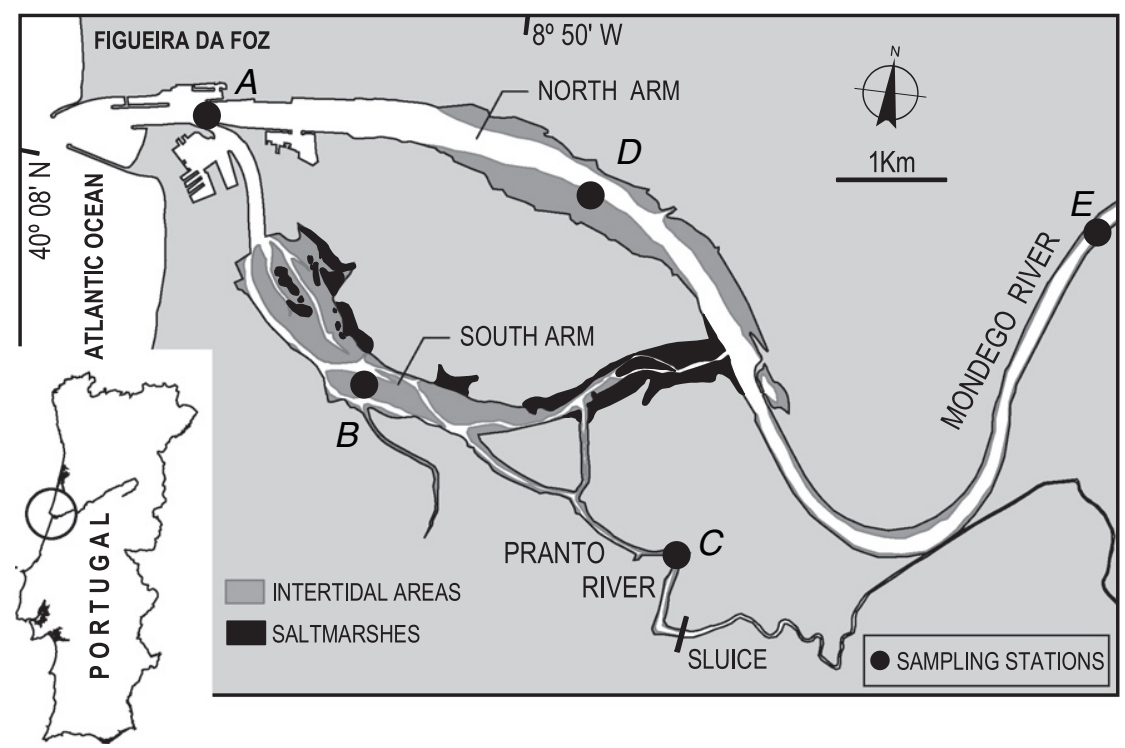

Fig. 1. The Mondego River Estuary - location of the five sampling stations. 
by a sluice according to the water needs in the surrounding rice fields. In the south arm, about $75 \%$ of the total area consists of intertidal mudflats, while in the north arm they stand for less than $10 \%$.

The main point sources of pressure and disturbance in the Mondego are the following: (a) dredging and shipping in the north arm; and (b) raw sewage disposal and high nutrient inputs from agricultural and fish farms in the upstream areas of the south arm. Combined with a high water residence time, this led to an eutrophication process, resulting in occasional spring macroalgae blooms of Enteromorpha spp. over the past two decades (e.g. Pardal et al., 2004; Dolbeth et al., 2007). As a result the ancient large meadows of Zostera noltii are restricted to a small patch in the downstream area (Cardoso et al., 2004).

\subsection{Sampling procedures and hydrological data}

The fish community was sampled monthly at five stations (Fig. 1), from June 2003 to June 2006 (except in July, September, October and December 2004, due to technical constraints). Fishing took place during the night, at high water of spring tides, using a 2-m beam trawl with one tickler chain and $5 \mathrm{~mm}$ mesh size in the cod end. At each station, three trawls were towed for an average of $5 \mathrm{~min}$ each, covering at least an area of $500 \mathrm{~m}^{2}$. All the fish caught were identified and counted. Bottom water was analyzed for temperature, salinity, dissolved oxygen and $\mathrm{pH}$ while fishing took place.

Hydrological data were obtained from INAG - Portuguese Water Institute (http://snirh.inag.pt). Both monthly precipitation (from January 2002 to June 2006) and long-term monthly average precipitation (from 1933 to 2006) were obtained from the Soure $13 \mathrm{~F} / 01 \mathrm{G}$ station. Freshwater runoff was acquired from INAG station Açude Ponte Coimbra 12G/01A, near the city of Coimbra (located $40 \mathrm{~km}$ upstream).

\subsection{Data analysis}

The community structure was analyzed based on six ecological guilds established from habitat pattern usage (adapted from Elliott and Dewailly, 1995): marine adventitious species (MA), marine juvenile migrant species (MJ; occurring usually in low densities in estuaries as an alternative habitat), marine species that use the estuary as nursery grounds $\mathrm{NU}$; occurring in clear seasonal patterns, higher densities and remaining longer periods in estuaries), estuarine resident species (ER), catadromous adventitious species (CA) (no anadromous species were found) and freshwater adventitious species (FW). Monthly fish abundance data were expressed as the number of individuals per $1000 \mathrm{~m}^{2}$. For a straightforward synthesis and analysis of the obtained results, monthly data were averaged by season, as follows: summer - from June to August; autumn - from September to November; winter - from December to February; and spring - from March to May. Whenever one or more months were absent, seasonal values were calculated with the available data. Spatial variability was not taken into account due to the small size of the estuary.
Multivariate statistics were used to investigate variations in the structure of the fish community throughout the study period. A Bray-Curtis similarity matrix was computed using seasonal abundances of fishes of each guild (square root transformed), from which the non-metric multidimensional scaling (MDS) ordination plot was generated using PRIMER software package (version 5.0) (Clarke and Warwick, 2001). To validate the interpretation of the MDS, the ANOSIM test (analysis of similarities) was performed, built on a simple nonparametric permutation procedure, applied to the similarity matrix underlying the ordination of the samples (treatments) (Clarke and Warwick, 2001). The BIOENV procedure (PRIMER software package, version 5.0) (Clarke and Warwick, 2001) (all permutations of trial variables, Spearman's rank correlation) was used to find the best combination of environmental variables explaining the variations in the fish community.

Salinity anomalies were calculated as the average monthly salinity subtracted from the corresponding average throughout the study period. Differences between years were tested using an ANOVA. Tukey-type a posteriori tests were used, whenever the null hypothesis was rejected. Spearman's rank correlations between fish abundance (per ecological guild) and environmental parameters were calculated. A significance level of 0.05 was considered in all test procedures.

\section{Results}

\subsection{Environmental characterization}

Considerable variations in precipitation and freshwater runoff were observed during the surveys. While in 2003/2004 precipitation values were higher than the 1931-2006 average, 2004 and 2005 were considered as extreme drought, with below average precipitation and low freshwater discharge (Fig. 2). Freshwater flow evidenced a severe reduction, with the lowest value in 2005 almost 10-fold lower than the highest in 2003.

Salinity was highly variable at all stations, particularly at the most upstream ones $(F=34.1, P<0.05)$. In 2005 , salinity values were higher in all stations than in the remaining years. This fact was particularly marked in station E (reaching 20 in September 2005). Significant differences were found between salinity values of 2003/2004 and 2004/2005 ( $q=0.006$, $P<0.05$, Tukey-type a posteriori test). Negative anomalies occurred mainly in 2003/2004, while positive anomalies occurred mostly in 2005, indicating higher than average salinity values (Fig. 3). For further detailed information on salinity variations in the sampling stations see Marques et al. (2007). Temperature showed a typical variation for the temperate regions, varying from $8.82 \pm 1.69^{\circ} \mathrm{C}$ to $22.74 \pm 2.55^{\circ} \mathrm{C}$ (Table 1).

\subsection{Fish assemblage}

Throughout the study period, a total of 10,697 individuals, belonging to 42 species and 23 families, comprised the Mondego Estuary fish assemblage (Table 2). The most abundant species were the estuarine residents (ER) Pomatoschistus 


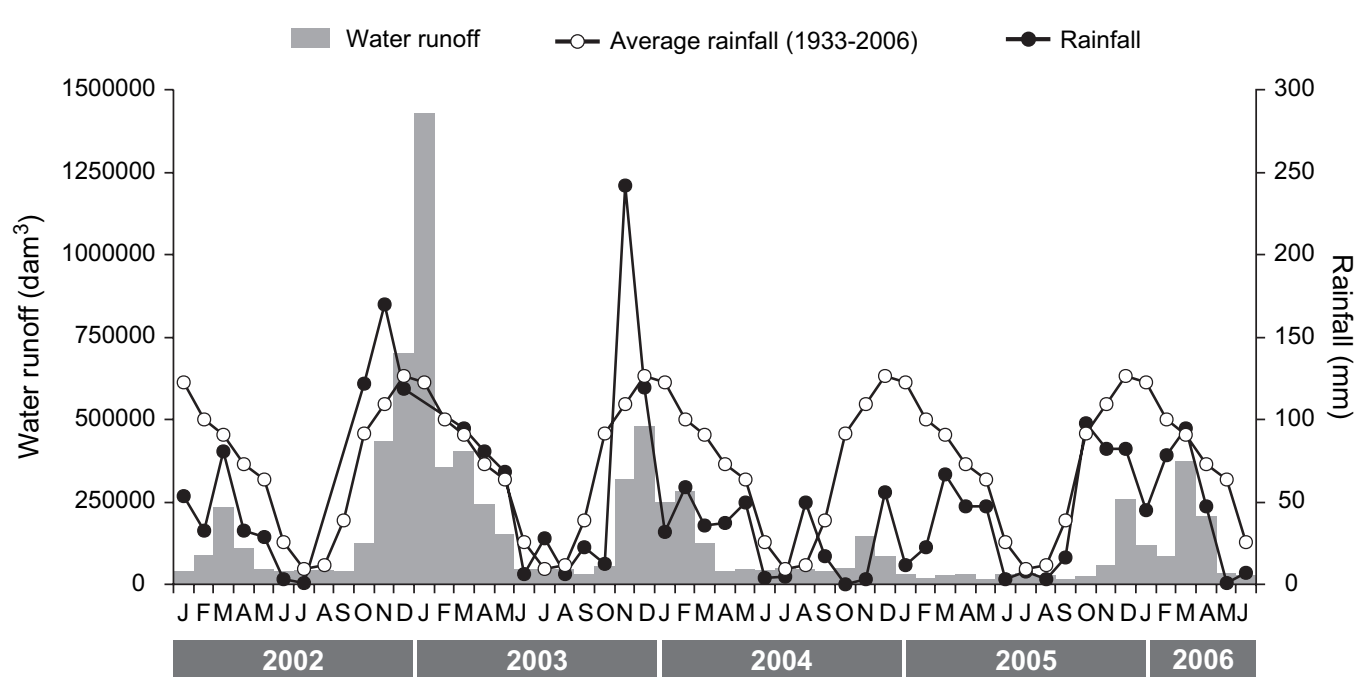

Fig. 2. Monthly precipitation and river runoff values from January 2002 to June 2006, plotted against the average precipitation values for $1933-2006$.

microps and Pomatoschistus minutus, the species that use the estuary as nursery grounds (NU) Dicentrarchus labrax, Solea solea and Platichthys flesus, and the marine juvenile migrant species (MJ) Diplodus vulgaris. Juvenile stages comprised most of the estuarine community (unpublished results).

Freshwater adventitious species (FW) (Barbus bocagei, Carassius auratus and Gambusia holbrooki) were only occasionally collected until the winter of 2004. Marine adventitious species (MA) such as Arnoglossus laterna, Buglossidium luteum, Gaidropsarus mediterraneus, Solea lascaris and Symphodus bailloni only appeared after the summer of 2004. In fact, A. laterna, B. luteum, S. lascaris and Trisopterus luscus were only captured inside the estuary throughout 2005 .

The number of species per month was constant over the study period, with an average number of $15( \pm 3)$. However, differences in the total number of species per year were observed, with the highest values recorded in 2005/2006 - 35 species, then 2003/2004 - 34 species, and finally 2004/2005 - 29 species.

Regarding the number of species per ecological guild (Fig. 4a), there was an increase in marine adventitious species
(MA) since the spring of 2005, comprising almost $25 \%$ of the species number. On the opposite, there was a decrease in marine juvenile migrant species (MJ). Estuarine residents (ER) and nursery species (NU) comprised about $50 \%$ of the species number. In terms of densities (Fig. 4b), the nursery species (NU) dominated the assemblage in 2003/2004, while in $2004 / 2005$ and $2005 / 2006$ the community was dominated by the estuarine residents (ER), particularly Pomatoschistus species, comprising about $75 \%$ of the community in the autumn of 2004 and spring and summer of 2006. In 2005, the relative abundance of marine adventitious species (MA) also increased.

The most significant changes in the fish assemblage were detected in three guilds: estuarine residents (ER), freshwater adventitious species (FW) and marine adventitious species (MA) (Fig. 5). Considering marine adventitious species (MA), there was an increase in densities mainly in 2005, during the period of extremely low precipitation and freshwater flow. In 2006, abundance values were similar to those found in 2003. An opposite pattern was found for estuarine residents (ER), with low densities in the driest periods (2004 and 2005). These species exhibited summer abundance peaks, but in

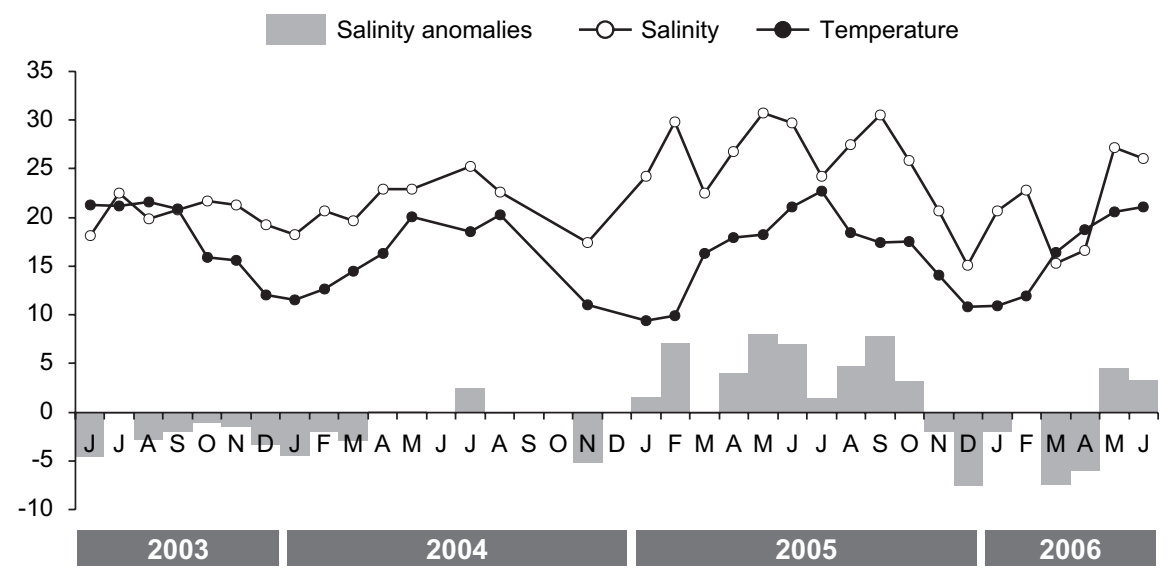

Fig. 3. Average monthly variation of bottom salinity, temperature $\left({ }^{\circ} \mathrm{C}\right)$ and salinity anomalies for the study period, in the Mondego Estuary. 
Table 1

Monthly variation (mean values \pm standard deviation) of bottom water salinity, temperature $\left({ }^{\circ} \mathrm{C}\right)$, dissolved oxygen $\left(\mathrm{mg} \mathrm{L}^{-1}\right)$ and $\mathrm{pH}$

\begin{tabular}{lllrl}
\hline Month & Salinity & $\begin{array}{l}\text { Temperature } \\
\left({ }^{\circ} \mathrm{C}\right)\end{array}$ & \multicolumn{1}{l}{$\mathrm{O}_{2}$} \\
& & $\left.\mathrm{mg} \mathrm{L}^{-1}\right)$ & $\mathrm{pH}$ \\
\hline Jun-03 & $18.10 \pm 11.52$ & $21.24 \pm 1.11$ & $5.53 \pm 0.72$ & $8.05 \pm 0.20$ \\
Jul-03 & $22.54 \pm 13.45$ & $21.22 \pm 3.61$ & $8.24 \pm 1.76$ & $8.04 \pm 0.26$ \\
Aug-03 & $19.86 \pm 12.22$ & $21.64 \pm 2.28$ & $8.09 \pm 1.71$ & $8.03 \pm 0.26$ \\
Sep-03 & $20.78 \pm 14.14$ & $20.88 \pm 1.26$ & $7.51 \pm 0.97$ & $7.95 \pm 0.16$ \\
Oct-03 & $21.68 \pm 13.34$ & $15.92 \pm 0.42$ & $9.29 \pm 1.07$ & $7.85 \pm 0.27$ \\
Nov-03 & $21.28 \pm 14.06$ & $15.62 \pm 0.28$ & $8.93 \pm 1.06$ & $7.86 \pm 0.44$ \\
Dec-03 & $19.28 \pm 11.88$ & $12.02 \pm 0.97$ & $10.76 \pm 1.13$ & $8.00 \pm 0.28$ \\
Jan-04 & $18.24 \pm 11.23$ & $11.52 \pm 1.52$ & $10.46 \pm 0.35$ & $7.89 \pm 0.27$ \\
Feb-04 & $20.64 \pm 13.01$ & $12.62 \pm 1.17$ & $9.77 \pm 1.39$ & $8.28 \pm 0.11$ \\
Mar-04 & $19.68 \pm 12.53$ & $14.46 \pm 1.48$ & $10.13 \pm 0.45$ & $8.31 \pm 0.22$ \\
Apr-04 & $22.88 \pm 10.82$ & $16.32 \pm 1.26$ & $9.98 \pm 1.02$ & $8.00 \pm 0.19$ \\
May-04 & $22.92 \pm 11.31$ & $20.04 \pm 2.71$ & $7.89 \pm 1.76$ & $8.10 \pm 0.19$ \\
Jun-04 & $25.25 \pm 12.49$ & $18.50 \pm 3.05$ & $7.53 \pm 1.19$ & $8.04 \pm 0.14$ \\
Aug-04 & $22.60 \pm 12.74$ & $20.24 \pm 2.73$ & $8.45 \pm 1.04$ & $7.99 \pm 0.46$ \\
Nov-04 & $17.44 \pm 10.22$ & $10.98 \pm 1.06$ & $9.52 \pm 0.48$ & - \\
Jan-05 & $24.28 \pm 10.58$ & $8.82 \pm 1.69$ & - & - \\
Feb-05 & $29.78 \pm 7.99$ & $9.92 \pm 0.38$ & $11.99 \pm 0.79$ & $8.28 \pm 0.04$ \\
Mar-05 & $22.54 \pm 12.97$ & $16.26 \pm 0.75$ & $9.57 \pm 1.37$ & $8.03 \pm 0.23$ \\
Apr-05 & $26.78 \pm 8.78$ & $17.94 \pm 1.78$ & $9.07 \pm 1.43$ & $8.13 \pm 0.21$ \\
May-05 & $30.72 \pm 6.28$ & $18.26 \pm 2.60$ & $9.08 \pm 1.18$ & $8.05 \pm 0.18$ \\
Jun-05 & $29.68 \pm 6.39$ & $21.04 \pm 2.91$ & $8.73 \pm 1.32$ & $7.81 \pm 0.16$ \\
Jul-05 & $24.24 \pm 11.67$ & $22.74 \pm 2.55$ & $7.62 \pm 1.30$ & $7.91 \pm 0.13$ \\
Aug-05 & $27.46 \pm 6.29$ & $18.42 \pm 2.29$ & $7.99 \pm 0.75$ & $8.06 \pm 0.09$ \\
Sep-05 & $30.48 \pm 6.63$ & $17.40 \pm 1.78$ & $8.63 \pm 0.92$ & $7.99 \pm 0.12$ \\
Oct-05 & $25.90 \pm 11.35$ & $17.56 \pm 0.67$ & $8.84 \pm 1.28$ & $7.92 \pm 0.10$ \\
Nov-05 & $20.66 \pm 13.73$ & $14.12 \pm 0.72$ & $8.24 \pm 0.21$ & - \\
Dec-05 & $15.14 \pm 10.91$ & $10.86 \pm 0.94$ & - & - \\
Jan-06 & $20.70 \pm 13.14$ & $10.92 \pm 1.36$ & $10.06 \pm 0.59$ & $7.72 \pm 0.07$ \\
Feb-06 & $22.78 \pm 8.17$ & $11.93 \pm 0.88$ & $10.59 \pm 0.53$ & $7.78 \pm 0.13$ \\
Mar-06 & $15.28 \pm 14.26$ & $16.44 \pm 1.28$ & $9.25 \pm 0.42$ & $8.37 \pm 0.14$ \\
Apr-06 & $16.64 \pm 14.82$ & $18.76 \pm 2.27$ & $8.41 \pm 1.20$ & $8.08 \pm 0.36$ \\
May-06 & $27.20 \pm 9.86$ & $20.58 \pm 3.37$ & $8.00 \pm 1.04$ & $8.02 \pm 0.12$ \\
Jun-06 & $26.06 \pm 6.02$ & $21.04 \pm 2.36$ & $8.02 \pm 0.85$ & $7.99 \pm 0.16$ \\
\hline & & & &
\end{tabular}

higher magnitude in 2003 and 2006. Freshwater adventitious species (FW) were last recorded in estuarine waters in the winter of 2004 and in very low densities. Taking into account marine juvenile migrant species (MJ) and nursery species (NU), a decrease in densities was also observed along the study period.

\subsection{Statistical analysis of the fish assemblage}

The fish community (based on the ecological guilds) was seasonally separated in the MDS ordination plot, particularly the years of 2003 and 2006 (Fig. 6). Differences between seasons and years were identified, mainly in 2003 and 2006, which were further separated from the remaining years. Furthermore, 2006 exhibited high variability among seasons, showing the greatest scatter within the same year. Both summers of 2003 and 2006 were closely linked in the ordination plot. All seasons of 2004 and 2005 were closer in the diagram, along with the spring of 2006. An opposition between the autumn of 2003 and 2004 was observed.
Significant differences were detected with ANOSIM between years at the 5\% level: 2005 was significantly different from $2006(R=0.426 ; P=0.029)$. Although not significantly, differences were also found between 2003 and 2004 $(R=0.857 ; P=0.067)$ and between 2003 and $2005(R=1$; $P=0.067)$. BIOENV procedure revealed that dissolved oxygen, $\mathrm{pH}$ and precipitation were responsible for explaining $34 \%$ of the variability within the fish community.

Spearman's rank correlations of the abundance of each ecological guild with the environmental conditions showed a positive correlation of the nursery and residents' guilds with temperature $(r=0.56 ; P<0.05$ and $r=0.64 ; P<0.05$, respectively) (Table 3 ). Negative correlations were found between the estuarine residents and precipitation $(r=-0.54$; $P<0.05)$ and between marine adventitious and water runoff $(r=-0.81 ; P<0.05)$.

\section{Discussion}

\subsection{Fish community}

The Mondego Estuary fish assemblage was similar to the typical European Atlantic seaboard estuarine community as defined by Elliott and Dewailly (1995), Pihl et al. (2002) and by Mathieson et al. (2000) for tidal marshes, with a dominance of estuarine residents (ER) and species that use estuaries as nursery areas (NU). The present results corroborate the findings of Malavasi et al. (2004), in which the estuarine residents comprise about $50 \%$ of the fish community of the Venice Lagoon. Unlike larger estuaries, marine juvenile migrant species (MJ) were less important in both number of species and total densities. Pihl et al. (2002) found that within a group of selected estuarine systems, great regional variance exists in the composition and abundance of the ecological guilds making up the estuarine fish assemblages, mainly due to particular characteristics of each estuarine system. This seems to agree with our results, as the differences found can be attributed to the small size of the Mondego Estuary and to its small opening, which can limit the entrance of marine species.

The most important families of the Mondego Estuary fish assemblage were Gobiidae, Moronidae, Soleidae, Pleuronectidae, Sparidae and Atherinidae. When comparing with other European estuarine systems (e.g. Laffaille et al., 2000; Cabral et al., 2001; Gordo and Cabral, 2001; Potter et al., 2001; Costa et al., 2002; Hampel et al., 2003; Malavasi et al., 2004), the main difference that can be found is the absence of Mugilidae as one of the most important families. Beam trawling is often considered a suitable method for sampling benthic species, but tends to underestimate pelagic species (Thiel et al., 2003) such as mugilids.

The nursery species (NU) Dicentrarchus labrax, Platichthys flesus and Solea solea comprised a significant part of the assemblage, in conformity with other European estuaries (e.g. Elliott and Dewailly, 1995; Laffaille et al., 2000; Gordo and Cabral, 2001; Malavasi et al., 2004), reinforcing the importance of small estuaries as nursery areas and their role for the maintenance of coastal stocks. As outlined by Martinho et al. 
Table 2

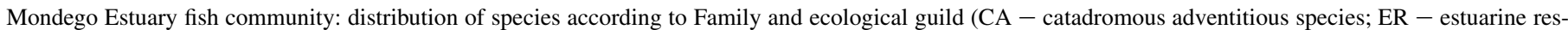

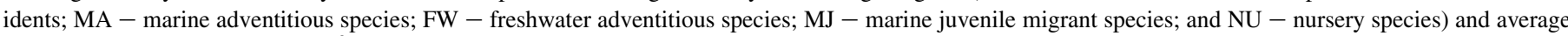
number of individuals per $1000 \mathrm{~m}^{2}$ for all the study periods

\begin{tabular}{|c|c|c|c|c|c|c|c|}
\hline Species & Family & $\begin{array}{l}\text { Ecological } \\
\text { guild }\end{array}$ & $\begin{array}{l}\text { Average } N \\
\text { ind. } 1000 \mathrm{~m}^{-2}\end{array}$ & Species & Family & $\begin{array}{l}\text { Ecological } \\
\text { guild }\end{array}$ & $\begin{array}{l}\text { Average } N \\
\text { ind. } 1000 \mathrm{~m}^{-2}\end{array}$ \\
\hline Ammodytes tobianus & Ammodytidae & MA & $0.119 \pm 0.34$ & Liza aurata & Mugilidae & MJ & $0.014 \pm 0.04$ \\
\hline Anguilla anguilla & Anguillidae & $\mathrm{CA}$ & $0.633 \pm 0.94$ & Liza ramada & Mugilidae & $\mathrm{CA}$ & $0.250 \pm 0.58$ \\
\hline Aphia minuta & Gobiidae & MA & $0.062 \pm 0.22$ & Mugil cephalus & Mugilidae & MJ & $0.005 \pm 0.02$ \\
\hline Arnoglossus laterna & Scophthalmidae & MA & $0.016 \pm 0.06$ & Mullus surmuletus & Mullidae & MJ & $0.104 \pm 0.17$ \\
\hline Atherina boyeri & Atherinidae & ER & $0.789 \pm 1.29$ & Nerophis lumbriciformis & Syngnathidae & ER & $0.008 \pm 0.05$ \\
\hline Atherina presbyter & Atherinidae & ER & $0.098 \pm 0.21$ & Parablennius gattorugine & Blenniidae & MA & $0.003 \pm 0.02$ \\
\hline Barbus bocagei & Cyprinidae & FW & $0.007 \pm 0.04$ & Platichthys flesus & Pleuronectidae & $\mathrm{NU}$ & $1.501 \pm 1.64$ \\
\hline Buglossidium luteum & Soleidae & MA & $0.003 \pm 0.02$ & Pomatoschistus microps & Gobiidae & ER & $8.155 \pm 11.58$ \\
\hline Callionymus lyra & Callionymidae & MA & $0.148 \pm 0.27$ & Pomatoschistus minutus & Gobiidae & ER & $3.685 \pm 6.04$ \\
\hline Carassius auratus & Cyprinidae & FW & $0.002 \pm 0.01$ & Sardina pilchardus & Clupeidae & MJ & $0.275 \pm 1.10$ \\
\hline Chelon labrosus & Mugilidae & MJ & $0.009 \pm 0.04$ & Scophthalmus rhombus & Scophthalmidae & MJ & $0.050 \pm 0.07$ \\
\hline Ciliata mustela & Gadidae & MJ & $0.129 \pm 0.21$ & Solea lascaris & Soleidae & MA & $0.025 \pm 0.07$ \\
\hline Conger conger & Congridae & MA & $0.018 \pm 0.04$ & Solea senegalensis & Soleidae & MJ & $0.099 \pm 0.15$ \\
\hline Dicentrarchus labrax & Moronidae & $\mathrm{NU}$ & $7.507 \pm 7.93$ & Solea solea & Soleidae & $\mathrm{NU}$ & $1.663 \pm 1.42$ \\
\hline Dicologlossa hexophthalma & Soleidae & MJ & $0.002 \pm 0.01$ & Sparus aurata & Sparidae & MJ & $0.020 \pm 0.05$ \\
\hline Diplodus vulgaris & Sparidae & MJ & $1.422 \pm 1.84$ & Spondyliosoma cantharus & Sparidae & MA & $0.018 \pm 0.07$ \\
\hline Echiichthys vipera & Trachinidae & MA & $0.027 \pm 0.07$ & Symphodus bailloni & Labridae & MA & $0.047 \pm 0.11$ \\
\hline Engraulis encrasicolus & Engraulidae & MA & $0.052 \pm 0.17$ & Syngnathus abaster & Syngnathidae & ER & $0.165 \pm 0.25$ \\
\hline Gaidropsarus mediterraneus & Gadidae & MA & $0.002 \pm 0.01$ & Syngnathus acus & Syngnathidae & ER & $0.257 \pm 0.52$ \\
\hline Gambusia holbrooki & Poeciliidae & FW & $0.011 \pm 0.06$ & Trigla lucerna & Triglidae & MJ & $0.120 \pm 0.26$ \\
\hline Gobius niger & Gobiidae & ER & $0.124 \pm 0.14$ & Trisopterus luscus & Gadidae & MA & $0.102 \pm 0.24$ \\
\hline
\end{tabular}

(2007), seasonal abundance peaks for these species were recorded, and directly linked to the seasonal patterns of recruitment and migration between enclosed and coastal waters. In terms of numbers, the fish community was dominated by Pomatoschistus microps. This estuarine residents (ER) were the most abundant since the autumn of 2004, and in agreement with
Leitão et al. (2006), tend to occupy inner areas of the estuary, thus reducing competition with other Gobiidae species such as Pomatoschistus minutus, which is mainly concentrated at the mouth of the estuary (Leitão et al., 2006; Dolbeth et al., 2007).

One significant aspect of this work was the reappearance of Symphodus bailloni, a marine species that lives in association
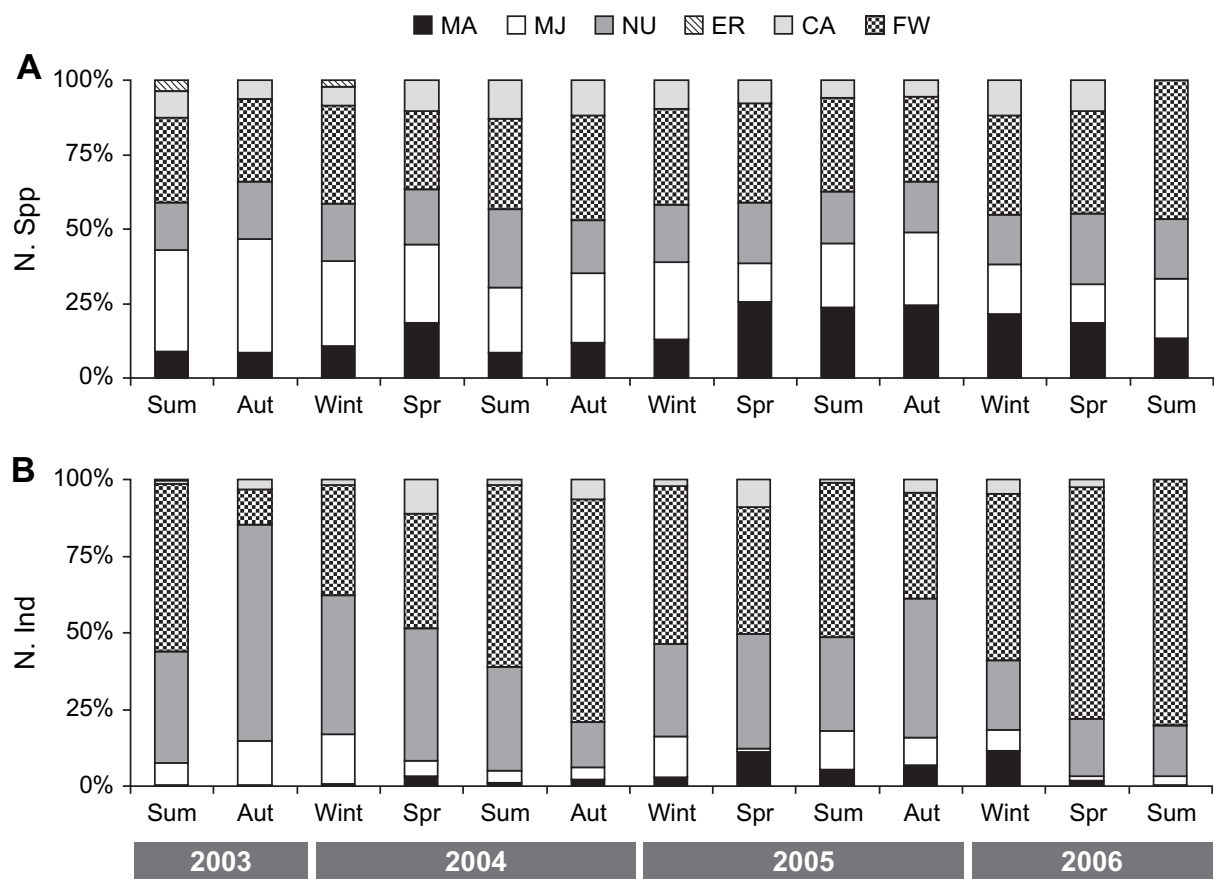

Fig. 4. Seasonal variation of the relative composition of each ecological guild, according to the number of species (A) and number of individuals per $1000 \mathrm{~m}^{2}$ (B). CA - catadromous adventitious species; ER - estuarine residents; MA - marine adventitious species; FW - freshwater adventitious species; MJ - marine juvenile migrant species; and NU - nursery species. Sum - summer; Aut - autumn; Wint - winter; and Spr - spring. 

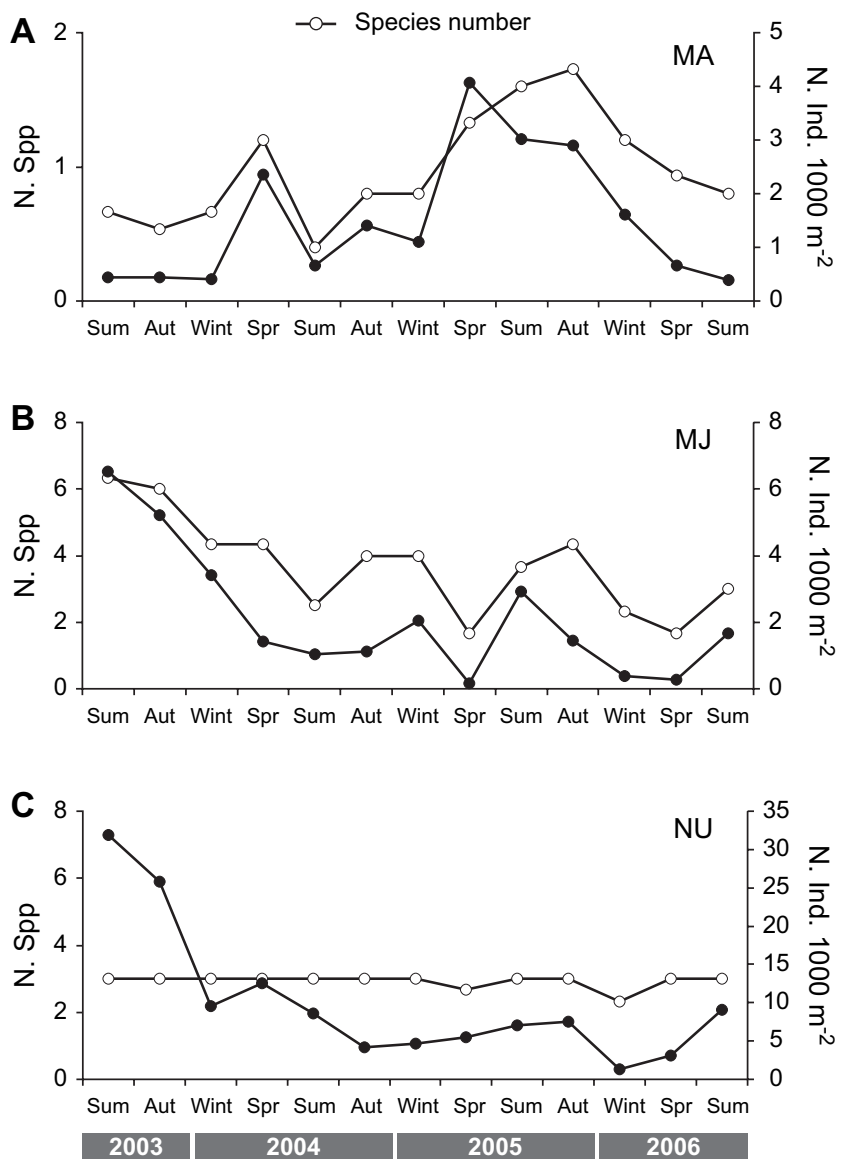
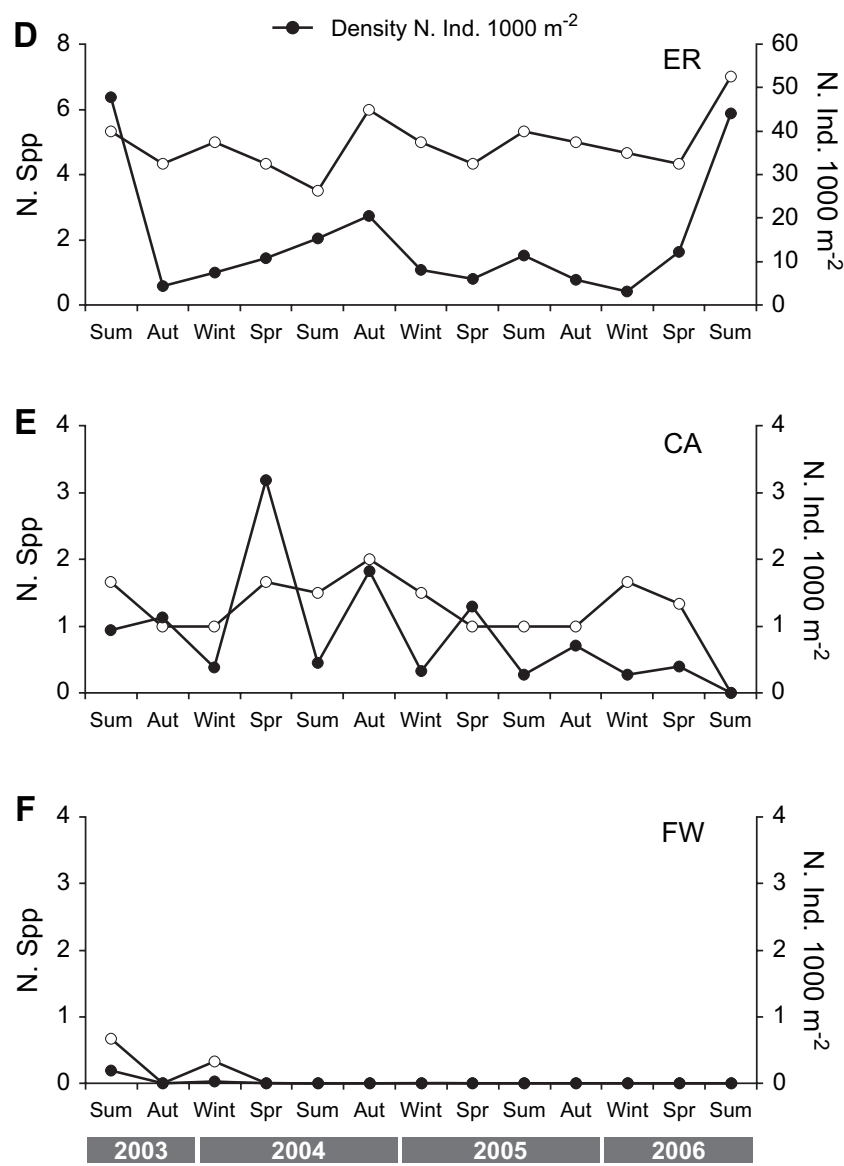

Fig. 5. Seasonal variation of the species number and number of individuals per $1000 \mathrm{~m}^{2}$ of each ecological guild, A - marine adventitious species (MA); B marine juvenile migrant species (MJ); C - nursery species (NU); D - estuarine residents (ER); E - catadromous adventitious species (CA); and F - freshwater (FW). Sum - summer; Aut - autumn; Wint - winter; and Spr - spring.

with seagrass beds. This species had been captured in the previous study performed by Jorge et al. (2002) in the early 1990 s, but was absent until the summer of 2004. The relevance of this finding can be related to the success of the eutrophication mitigation measures implemented in the estuary since 1998 (for further details see Lillebø et al., 2005), which led to a recovery of the area covered by Zostera noltii ( 15 ha in 1986; 0.02 ha in 1997; and 4.7 ha in 2006) in the south arm of the estuary, increasing the available habitat for this species. Currently, a management program is taking place, in order to restore the communication of the north and south arms, to improve the water circulation and to reduce the residence time, aiming at the restoration of the seagrass meadows.

\subsection{Extreme drought events and its impacts on fish assemblages}

Having in mind that the measurement of any ecological response by the fish community, or individual species within a community, must take cognisance on the key role played by the physico-chemical environment in influencing the structure and functioning of that estuary (Whitfield and Elliott, 2002), this work tried to assess the influence of extreme drought events in the fish community.
Due to the occurrence of two consecutive extreme dry years, several changes occurred in the Mondego River basin. In fact, according to the Portuguese Weather Institute (http:// web.meteo.pt/pt/clima/clima.jsp), in these last years severe

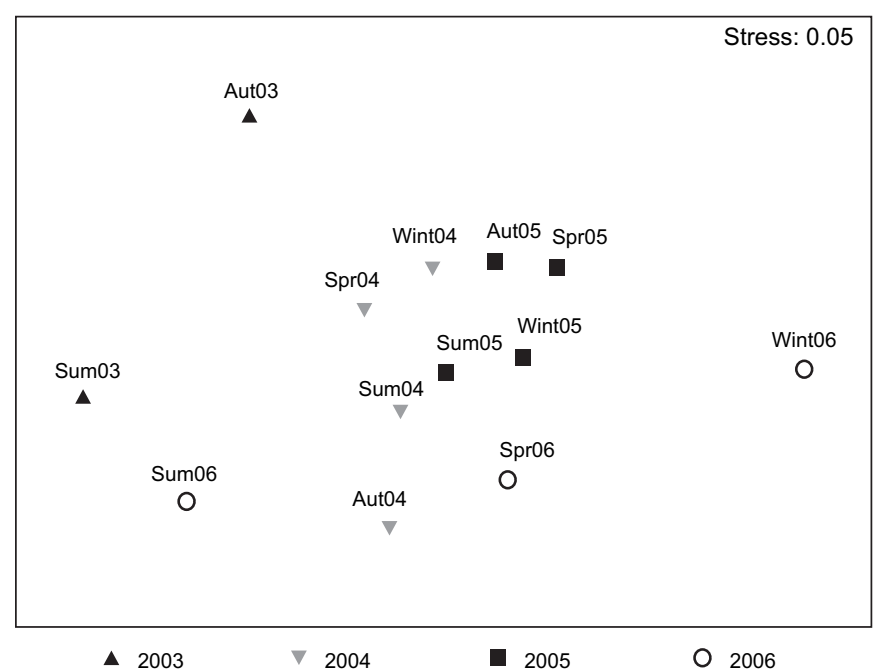

Fig. 6. Two-dimensional MDS ordination plot of the fish community according to season. Sum - summer; Aut - autumn; Wint - winter; and Spr - spring. 
Table 3

Spearman rank correlations between the average abundance of fishes of each ecological guild and some environmental parameters. Sal - salinity; Temp temperature; $\mathrm{O}_{2}$ - dissolved oxygen; $\mathrm{pH}-\mathrm{pH}$; Avg Precip - average precipitation; and Avg Runoff - average river runoff. *Are significant values for $P<0.05$

\begin{tabular}{lclcccc}
\hline Guild & Sal & $\begin{array}{l}\text { Temp } \\
\left({ }^{\circ} \mathrm{C}\right)\end{array}$ & $\begin{array}{l}\mathrm{O}_{2} \\
\left(\mathrm{mg} \mathrm{L}^{-1}\right)\end{array}$ & $\mathrm{pH}$ & $\begin{array}{l}\text { Avg Precip } \\
(\mathrm{mm})\end{array}$ & $\begin{array}{l}\text { Avg Runoff } \\
\left(\mathrm{da} \mathrm{m}^{3}\right)\end{array}$ \\
\hline MA & 0.49 & 0.00 & 0.26 & 0.23 & 0.24 & $-0.81^{*}$ \\
MJ & 0.24 & 0.34 & 0.27 & -0.01 & 0.05 & 0.05 \\
NU & 0.24 & $0.56^{*}$ & 0.06 & 0.18 & 0.17 & 0.05 \\
ER & 0.18 & $0.64^{*}$ & -0.36 & 0.51 & $-0.54^{*}$ & -0.16 \\
CA & 0.01 & 0.11 & 0.29 & 0.48 & 0.29 & -0.06 \\
FW & 0.01 & 0.43 & 0.17 & 0.38 & 0.17 & -0.05 \\
\hline
\end{tabular}

differences in climate have been recorded when compared to the general climate patterns for the period 1961-1990. With decreasing precipitation levels and in an extreme drought situation, freshwater was stored in dams located upstream, which led to a decrease in water runoff to the estuary, from 2004 to 2005. According to Whitfield (1999), variations in the river flow in estuaries influence not only the salinity but also the biochemical properties of the water body. Furthermore, decreasing freshwater flow results in the incursion of saline waters into reaches of the estuary previously dominated by freshwater (Attrill et al., 1996), and in agreement, strong positive salinity anomalies were observed mainly in 2005, indicating that values higher than average salinity occurred throughout the estuary.

Typical marine adventitious species (MA) like Arnoglossus laterna, Buglossidium luteum, Solea lascaris and Trisopterus luscus were only captured in the estuary during the period where the highest drought effects were experienced -2005 , benefiting from a higher extent of the incursion of seawater

Table 4

Species abundance ranking ( $\%$ of number of individuals per $1000 \mathrm{~m}^{2}$ ) for the periods of 2003/2004, 2004/2005 and 2005/2006. Only the 20 most abundant species are shown

\begin{tabular}{|c|c|c|c|c|c|}
\hline \multicolumn{2}{|l|}{$2003 / 2004$} & \multicolumn{2}{|l|}{$2004 / 2005$} & \multicolumn{2}{|l|}{$2005 / 2006$} \\
\hline Species & $\%$ & Species & $\%$ & Species & $\%$ \\
\hline D. labrax & 34.58 & P. microps & 42.85 & P. microps & 40.43 \\
\hline P. microps & 20.31 & D. labrax & 15.89 & D. labrax & 17.79 \\
\hline P. minutus & 17.55 & P. flesus & 8.70 & P. minutus & 8.79 \\
\hline D. vulgaris & 7.00 & S. solea & 5.92 & S. solea & 7.05 \\
\hline$P$. flesus & 5.69 & P. minutus & 5.79 & A. boyeri & 6.82 \\
\hline S. solea & 5.52 & D. vulgaris & 3.46 & P. flesus & 2.64 \\
\hline A. anguilla & 2.46 & A. boyeri & 3.38 & S. pilchardus & 2.39 \\
\hline S. acus & 0.89 & A. anguilla & 3.34 & D. vulgaris & 2.09 \\
\hline A. boyeri & 0.86 & A. tobianus & 1.47 & S. acus & 1.20 \\
\hline L. ramada & 0.78 & L. ramada & 1.33 & A. anguilla & 1.19 \\
\hline S. pilchardus & 0.62 & C. lyra & 1.22 & T. luscus & 1.11 \\
\hline T. lucerna & 0.60 & S. abaster & 1.13 & C. lyra & 1.04 \\
\hline C. mustela & 0.56 & S. acus & 0.64 & M. surmuletus & 0.90 \\
\hline S. abaster & 0.44 & C. arautus & 0.61 & L. ramada & 0.89 \\
\hline G. niger & 0.39 & A. presbyter & 0.55 & A. presbyter & 0.86 \\
\hline A. minuta & 0.28 & E. encrasicolus & 0.55 & S. senegalensis & 0.74 \\
\hline S. rhombus & 0.25 & G. niger & 0.50 & S. abaster & 0.58 \\
\hline S. senegalensis & 0.21 & M. surmuletus & 0.48 & G. niger & 0.55 \\
\hline A. tobianus & 0.17 & S. bailloni & 0.45 & C. mustela & 0.43 \\
\hline E. vipera & 0.12 & T. luscus & 0.41 & E. encrasicolus & 0.36 \\
\hline
\end{tabular}

into the estuary (due to low freshwater runoff). In fact, none of these species had ever been described in the Mondego Estuary, according to the baseline study performed by Jorge et al. (2002) in the early 1990s. This points out an increase in salinity over the past decade inside the estuary, related to the effects of low freshwater flow combined with continuous dredging activities in the north arm (the location of the commercial harbour) which increases the salinity incursion inside the estuary (e.g. Marchand et al., 2002; Leitão et al., 2007).

According to the present data, it was possible to define three distinct periods in terms of environmental conditions: (a) 2004 and 2005, when the harshest drought-induced effects were felt; (b) 2003, when precipitation levels were considered normal; and (c) 2006, when precipitation levels were slightly lower than normal/regular years. These periods were identified in the MDS plot, showing the seasons of 2004 and 2005 grouped together, and although high dissimilarity between 2003 and 2006 was detected, summer values of both years look similar. This indicates that the changes in the fish community due to the effects of low precipitation and freshwater flow were more significant in 2004/2005. Accordingly, the main changes in the fish community were the depletion of freshwater adventitious species (FW) and an increase in marine adventitious species (MA), supported by the strong negative correlation between marine adventitious species (MA) and freshwater runoff, and a decrease in abundance of the estuarine residents (ER) during the driest period. The increase in marine adventitious species (MA) had already been reported in 1992 by Jorge et al. (2002), as a consequence of a hydrological dry year. The opposition found between the autumn of 2003 and autumn of 2004 seems to be caused by a shift in the relative proportions of estuarine residents (ER) and nursery species (NU). In addition, the ordination of samples in the MDS plot suggests that the fish community showed more seasonal changes in wet years than in dry years, as previously observed by Potter et al. (1986) and Cuesta et al. (2006) in other temperate estuaries. As outlined in the BIONEV analysis, precipitation was one of the environmental parameters best explaining the variability in the fish community.

References of the impacts of drought events on temperate estuarine fish communities are scarce in literature, with more available information on planktonic (e.g. Marques et al., 2007) and invertebrate benthic communities (e.g. Attrill et al., 1996; Attrill and Power, 2000; Cuesta et al., 2006). The previous authors concluded that in years of low freshwater flow, and mainly in the upper reaches of estuarine areas, freshwater communities were gradually replaced by others tolerant to higher salinities due to a higher saline incursion. This seems to corroborate the present results, even if comparing different trophic levels. Furthermore, Attrill and Power (2000) pointed out that fluctuations in key benthic species such as Carcinus maenas or Crangon crangon in response to climatic changes can induce variations in the whole estuarine community. Drake et al. (2002) suggested that short-term salinity fluctuations during warmer periods may negatively affect species that complete their lifecycle within the estuary. Likewise, the estuarine residents (ER) presented lower densities during the dry period 
and according to Fonds and Van Buurt (1974), the mortality of Pomatoschistus microps and Pomatoschistus minutus' eggs (the most abundant resident species) is highly dependent on salinity, conditioning the recruitment's strength (maximum egg survival at 5-35 with maximum larval size at 5-15 for $P$. microps and, $15-35$ for maximum egg survival with maximum larval size at 35 for $P$. minutus). Also, predation pressure on these species could have increased due to the higher abundance of marine adventitious species (MA), particularly at the mouth of the estuary (for further discussion on this topic see Dolbeth et al., 2007). According to Garcia et al. (2001), surveys in a warm-temperate south-western Atlantic intermittently closed lagoon (South Brazil) led to the conclusion that during La Niña episodes (cold and dry events) there was an increase in marine species inside the lagoon, as a consequence of low freshwater input and a higher intrusion of sea water into the upper reaches. The same pattern was observed by Ecoutin et al. (2005) in a coastal lagoon in the Ivory Coast.

However, and despite the changes described above, the majority of the fish assemblage remained rather unchanged. In the three years of sampling, the 10 most abundant species always comprised more than $90 \%$ of the number of individuals of the fish community, comprising the main core of the community (Table 4) and indicating that the major changes occurred in species with lower frequencies. Similar results were obtained by Costa et al. (2007) for the Tagus Estuary, when comparing various sampling periods from 1978 to 2002. The previous authors reported that the structure of the fish community remained relatively unchanged during subsequent dry and wet years, although higher densities were recorded in dry years. To assess whether climatic extremes have long term and more significant impacts on estuarine fish communities will require even longer and geographically wider databases, due to the slow response time to disturbance that characterizes fish species (Cabral et al., 2001).

In conclusion, and despite interannual variations in recruitment and mortality rates, it was possible to assess some effects of extreme drought events on a temperate estuarine fish community. This influence seems to be increased in the case of the Mondego due to its small area $\left(3.4 \mathrm{~km}^{2}\right)$, with lower thresholds to fast environmental variations. Moreover, and in conformity with Attrill et al. (1996), the influence of severe drought conditions, which are predicted to increase over the subsequent years, should be strongly considered when undertaking management plans for estuaries and river catchment areas. Also, prolonging ongoing monitoring programs should be encouraged, in order to understand the long-term effects of climatic changes in key systems such as the estuarine environment. The use of ecological guilds proved to be a strong tool in assessing changes in the estuarine system by reducing variability and allowing direct comparisons between estuaries in the future.

\section{Acknowledgements}

This work was supported by Instituto de Investigação Interdisciplinar - Universidade de Coimbra (III-UC), through a $\mathrm{PhD}$ grant attributed to $\mathrm{F}$. Martinho (III/AMB/33/2005) and through a Research project "Os recursos pesqueiros no âmbito da política europeia de desenvolvimento sustentável: uma abordagem interdisciplinar para o caso do robalo (Dicentrarchus labrax)" (III/AMB/4/2005). The authors wish to thank Heliana Teixeira, Daniel Crespo and Tiago Verdelhos, who assisted in field work and also to the three referees, who contributed greatly to the final manuscript.

\section{References}

Attrill, M.J., Rundle, S.D., Thomas, R.M., 1996. The influence of droughtinduced low freshwater flow on an upper-estuarine macroinvertebrate community. Water Research 30, 261-268.

Attrill, M.J., Power, M., 2000. Effects on invertebrate populations of droughtinduced changes in estuarine water quality. Marine Ecology Progress Series 203, 133-143.

Cabral, H.N., Costa, M.J., Salgado, P., 2001. Does the Tagus estuary fish community reflect environmental changes? Climate Research 18, 119-126.

Cardoso, P.G.M., Pardal, M.A., Lillebø, A.I., Ferreira, S.M., Raffaelli, D., Marques, J.C., 2004. Dynamics change in seagrass assemblages under eutrophication and implication for recovery. Journal of Experimental Marine Biology and Ecology 302, 233-248.

Clarke, K.R., Warwick, R.M., 2001. Change in Marine Communities. An Approach to Statistical Analysis and Interpretation, second ed. Primer-E, Plymouth.

Costa, M.J., Cabral, H.N., Drake, P., Economou, A.N., Fernandez-Delgado, C., Gordo, L., Marchand, J., Thiel, R., 2002. Recruitment and production of commercial species in estuaries. In: Elliott, M., Hemingway, K. (Eds.), Fishes in Estuaries. Blackwell Science, Iowa, pp. 56-123.

Costa, M.J., Vasconcelos, R., Costa, J.L., Cabral, H.N., 2007. River flow influence on the fish community of the Tagus estuary (Portugal). Hydrobiologia 587, 113-123.

Cuesta, J.A., González-Ortegón, E., Rodríguez, A., Baldó, F., Vilas, C., Rake, P., 2006. The decapod crustacean community of the Guadalquivir estuary (SW Spain): seasonal and inter-year changes in community structure. Hydrobiologia 557, 85-95.

Dolbeth, M., Cardoso, P.G., Ferreira, S.M., Verdelhos, T., Raffaelli, D., Pardal, M.A., 2007. Anthropogenic and natural disturbance effects on a macrobenthic estuarine community over a ten-year period. Marine Pollution Bulletin 54, 576-585.

Dolbeth, M., Martinho, F., Leitão, R., Cabral, H., Pardal, M.A., 2007. Strategies of Pomatoschistus minutus and Pomatoschistus microps to cope with environmental instability. Estuarine, Coastal and Shelf Science 74, 263-273.

Drake, P., Arias, A.M., Baldó, F., Cuesta, J.A., Rodríguez, A., Silva.García, A., Sobrino, I., Garcia-González, D., Fernández-Delgado, C., 2002. Spatial and temporal variation of the nekton and hyperbenthos from a temperate European estuary with regulated freshwater inflow. Estuaries 25, 451-468.

Ecoutin, J.-M., Richard, E., Simier, M., Albaret, J.-J., 2005. Spatial versus temporal patterns in fish assemblages of a tropical estuarine coastal lake: the Ebrié lagoon (Ivory Coast). Estuarine Coastal and Shelf Science 64, 623-635.

Elliott, M., Dewailly, F., 1995. The structure and components of European estuarine fish assemblages. Netherlands Journal of Aquatic Ecology 29, 397-417.

Fonds, M., Van Buurt, G., 1974. Netherlands Institute for Sea Research. Texol, The Netherlands, $110-116 \mathrm{pp}$.

Garcia, A.M., Vieira, J.P., Winemiller, K.O., 2001. Dynamics of the shallowwater fish assemblage of the Patos Lagoon estuary (Brazil) during cold and warm ENSO episodes. Journal of Fish Biology 59, 1218-1238.

Gleick, P., 2003. Global fresh water resources: soft-path solutions for the $21 \mathrm{st}$ century. Science 302, 1524-1528.

Gordo, L.S., Cabral, H.N., 2001. The fish assemblage structure of a hydrologically altered coastal lagoon: the Óbidos lagoon (Portugal). Hydrobiologia 459, 125-133. 
Haedrich, R.L., 1983. Estuarine fishes. In: Ketchum, B. (Ed.), Ecosystems of the World: Estuaries and Enclosed Seas. Elsevier, Amsterdam, pp. 183-207.

Hampel, H., Cattrijsse, A., Vincx, M., 2003. Habitat value of a developing estuarine brackish marsh for fish and macrocrustaceans. ICES Journal of Marine Science 60, 278-289.

INAG - Instituto Nacional da Água - Portuguese Water Institute. Available from: <http://snirh.inag.pt $>$ (accessed 04.05.07).

Jorge, I., Monteiro, C.C., Lasserre, G., 2002. Fish community of Mondego estuary: space-temporal organization. In: Pardal, M.A., Marques, J.C., Graça, M.A. (Eds.), Aquatic Ecology of the Mondego River Basin. Global Importance of Local Experience. Imprensa da Universidade de Coimbra, Coimbra, pp. 199-217.

Laffaille, P., Feunteun, E., Lefeuvre, J.-C., 2000. Composition of fish communities in a European macrotidal salt marsh (the Mont Saint-Michel Bay, France). Estuarine, Coastal and Shelf Science 51, 429-438.

Leitão, R., Martinho, F., Neto, J.M., Cabral, H.N., Marques, J.C., Pardal, M.A., 2006. Feeding ecology, population structure and distribution of Pomatoschistus microps (Krøyer, 1838) and Pomatoschistus minutus (Pallas, 1770) in a temperate estuary, Portugal. Estuarine, Coastal and Shelf Science 66, 231-239.

Leitão, R., Martinho, F., Cabral, H.N., Jorge, I., Marques, J.C., Pardal, M.A., 2007. The fish assemblage of the Mondego estuary: composition, structure and trends over the past two decades. Hydrobiologia 587, 269-279.

Lilleb $\varnothing$, A.I., Neto, J.M., Martins, I., Verdelhos, T., Leston, S., Cardoso, P.G., Ferreira, S.M., Marques, J.C., Pardal, M.A., 2005. Management of a shallow temperate estuary to control eutrophication: the effect of hydrodynamics on the system's nutrient loading. Estuarine, Coastal and Shelf Science 65, 697-707.

Malavasi, S., Fiorin, R., Franco, A., Franzoi, P., Granzotto, A., Riccato, F., Mainardi, D., 2004. Fish assemblages of Venice lagoon shallow waters: an analysis based on species, families and functional guilds. Journal of Marine Systems 51, 19-31.

Marchand, J., Codling, I., Drake, P., Elliott, M., Pihl, L., Rebelo, J., 2002. Environmental quality of estuaries. In: Elliott, M., Hemingway, K. (Eds.), Fishes in Estuaries. Blackwell Science, Iowa, pp. 322-409.

Marques, S.C., Azeiteiro, U.M., Martinho, F., Pardal, M.A., 2007. Climate variability and planktonic communities: the effect of an extreme event (severe drought) in a southern European estuary. Estuarine, Coastal and Shelf Science 73, 725-734.

Martinho, F., Leitão, R., Neto, J., Cabral, H.N., Marques, J.C., Pardal, M.A., 2007. The use of nursery areas by juvenile fish in a temperate estuary, Portugal. Hydrobiologia 587, 281-290.
Mathieson, S., Cattrijsse, A., Costa, M.J., Drake, P., Elliott, M., Gardner, J., Marchand, J., 2000. Fish assemblages of European tidal marshes: a comparison based on species, families and functional guilds. Marine Ecology Progress Series 204, 225-242.

McLusky, D.S., Elliott, M., 2004. The Estuarine Ecosystem: Ecology, Threats and Management, third ed. Oxford University Press, Oxford, 214 pp.

Mirza, M.M.Q., 2003. Climate change and extreme weather events: can developing countries adapt? Climate Policy 3, 233-248.

Pardal, M.A., Cardoso, P.G., Sousa, J.P., Marques, J.C., Raffaelli, D., 2004 Assessing environmental quality: a novel approach. Marine Ecology Progress Series 267, 1-8.

Pihl, L., Cattrijsse, A., Codling, I., Mathieson, S., McLusky, D.S., Roberts, C., 2002. Habitat use by fishes in estuaries and other brackish waters. In: Elliott, M., Hemingway, K. (Eds.), Fishes in Estuaries. Blackwell Science, Iowa, pp. 10-53.

Portuguese Weather Institute. Available from: <http://web.meteo.pt/pt/clima/ clima.jsp> (accessed 08.01.07).

Potter, I.C., Claridge, P.N., Warwick, R.M., 1986. Consistency of seasonal changes in an estuarine fish assemblage. Marine Ecology Progress Series 32, 217-228.

Potter, I.C., Bird, D.J., Claridge, P.N., Clarke, K.R., Hyndes, G.A., Newton, L.C., 2001. Fish fauna of the Severn estuary. Are there longterm changes in abundance and species composition and are the recruitment patterns of the main marine species correlated? Journal of Experimental Marine Biology and Ecology 258, 15-37.

Scheffer, M., Carpenter, S., Foley, J.A., Folke, C., Walker, B., 2001. Catastrophic shifts in ecosystems. Nature 413, 591-596.

Short, F.T., Neckles, H.A., 1999. The effects of global climate change on seagrasses. Aquatic Botany 63, 169-196.

Tallaksen, L.M., Madsen, H., Clausen, B., 1997. On the definition and modelling of streamflow drought duration and volume. Hydrological Sciences Journal 42, 15-33.

Thiel, R., Cabral, H., Costa, M.J., 2003. Composition, temporal changes and ecological guild classification of the ichthyofaunas of large European estuaries - a comparison between the Tagus (Portugal) and the Elbe (Germany). Journal of Applied Ichthyology 19, 330-342.

Whitfield, A.K., Elliott, M., 2002. Fishes as indicators of environmental and ecological changes within estuaries: a review of progress and some suggestions for the future. Journal of Fish Biology 61 (A), 229-250.

Whitfield, A.K., 1999. Ichthyofaunal assemblages in estuaries: a South African case study. Reviews in Fish Biology and Fisheries 9, 151-186. 